\title{
COMMENTS
}

\section{RECOVERY OF DAMAGES IN CLASS ACTIONS}

In December of 1961 the United States Court of Appeals for the Tenth Circuit added its voice to the quarter-century old debate on the function of the class action under rule 23 of the Federal Rules of Civil Procedure ${ }^{1}$ by permitting absent class members to participate in a judgment in favor of the class even though the court assumed that they would not have been bound by a judgment adverse to their interests. The case, Union Carbide \& Carbon Corp. v. Balsley, ${ }^{2}$ was a class action for treble damages brought by thirty-six vanadium mine owners against two large mining companies under section 4 of the Glayton Act $^{3}$ and sections 1 and 2 of the Sherman Act. ${ }^{4}$ In providing the four thousand absent mine owners with an opportunity to take advantage of the favorable decree the court expressly adopted the position advocated by Kalven and Rosenfield ${ }^{5}$ as against the majority view first urged upon the courts by Professor Moore. ${ }^{6}$ From the outset this debate has focused upon the class action as a means of recovering damages for an injured class, even though the class action is probably more important as a means of obtaining injunctive relief for a

1 FED. R. Crv. P. 23: “(a) Representation. If persons constituting a class are so numerous as to make it impracticable to bring them all before the court, such of them, one or more, as will fairly insure the adequate representation of all may, on behalf of all, sue or be sued, when the character of the right sought to be enforced for or against the class is (1) joint, or common, or secondary in the sense that the owner of a primary right refuses to enforce that right and a member of the class thereby becomes entitled to enforce it; (2) several, and the object of the action is the adjudication of claims which do or may affect specific property involved in the action; or (3) several, and there is a common question of law or fact affecting the several rights and a common relief is sought.

"(b) ...

“(c) Dismissal or Compromise. A class action shall not be dismissed or compromised without the approval of the court. If the right sought to be enforced is one defined in paragraph (l) of subdivision (a) of this rule notice of the proposed dismissal or compromise shall be given to all members of the class in such manner as the court directs. If the right is one defined in paragraphs (2) or (3) of subdivision (a) notice shall be given only if the court requires it."

2300 F.2d 561, 587-90 (10th Cir. 1961).

338 Stat. 731 (1914), 15 U.S.C. $\$ 15$ (1958).

426 Stat. 209 (1890), as amended, 15 U.S.C. $\$ \$ 1,2$ (1958).

5 Kalven \& Rosenfield, The Contemporary Function of the Class Suit, 8 U. CHI. L. REv. 684 (1941).

63 Moore, Federal Practice If 23.01-23.24 (2d ed. 1948). 
minority group which is the subject of illegal discrimination and of preventing multiple adjudications which might result in orders directing the defendant to adopt two or more irreconcilable courses of conduct. ${ }^{7}$ Since the Committee on Rules of Practice and Procedure of the Judicial Conference of the United States has proposed a drastic revision of rule $23,{ }^{8}$ an analysis of the class action as a device for the recovery of damages is timely.

In his treatise ${ }^{9}$ and earlier writings ${ }^{10}$ Professor Moore has set forth the understanding which apparently guided the Advisory Committee in drafting rule 23.11 According to Moore, the rule restates the prior learning on the subject of class actions by its tripartite classification of them according to the "jural relationships" of the members of the class. ${ }^{12}$ Beyond its being an exhaustive description of the circumstances in which a class suit may be maintained, rule 23 on its face attaches no significance to this classification. However, Moore states that this is so only because the Advisory Committee was of the opinion that the significance of the classification lay in areas of law more substantive than procedural ${ }^{13}$ and therefore outside the Committee's competence. What they really had in mind, we are told, was that each category of class action be keyed to historical differences in the extent to which the judgment in a class action would be binding on absent class members and to differences in federal jurisdictional requirements. ${ }^{14}$ Accordingly the "true" class action, corresponding to rule $23(\mathrm{a})(1)$, should function to bind in personam absentee members of the class whose joinder, but for the class action device, would be compulsory. Its secondary function should be to permit the jurisdic-

7 See Committee on Rules of Practice and Procedure of the Judicial Conference of the United States, Preliminary Draft of Proposed Amendments to Rules of Civil Procedure for the United States District Courts 95-98 (1964).

8 Ibid.

92 Moore, Federal Practice 1 f $23.01-23.04$ (1st ed. 1938).

10 Moore \& Cohn, Federal Class Actions-Jurisdiction and Effect of Judgment, 32 ILL. L. REv. 555 (1938); Moore \& Cohn, Federal Class Actions, 32 Inx. L. REv. 307 (1937).

11 United States Supreme Court, Rules of Civil Procedure for the District Courts of the United States with Index and Notes, S. Doc. No. 101, 76th Cong., Ist Sess. 240-42 (1939). The notes to rule 23 incorporate Moore's analysis by reference. However, with respect to the common question suit under subparagraph (3) the cases cited in the notes reached results different from those advocated by Moore in that they appear to hold that the judgment in a common question suit is binding upon the absentee members of the class. Note, Class Actions and Interpleader: California Procedure and the Federal Rules, 6 Stan. L. Rev. 120, 138-41 (1953).

12 Moore \& Cohn, Federal Class Actions, 32 ILL. L. Rev. 307, 314, 325 (1937).

13 See Moore, Federal Rules of Civil Procedure: Some Problems Raised by the Preliminary Draft, 25 GEo. L.J. 557, 570-76 (1937).

14 Moore \& Cohn, Federal Class Actions-Jurisdiction and Effect of Judgment, 32 ILL. L. REv. 555, 556 (1938). 
tional amount to be satisfied by aggregating the claims of the class members who are original parties to the suit. ${ }^{15}$ The "hybrid" class action, corresponding to rule 23(a)(2), should operate as a final adjudication of the rights of absent class members to specific property before the court, and as a device to circumvent the jurisdictional amount by requiring only that each of the class members who originally brought the action have a claim for the requisite amount. ${ }^{16}$ The "spurious" class action, corresponding to rule 23(a)(3) should function as a permissive joinder device which circumvents the requirement for a jurisdictional amount in the same manner as does the "hybrid" suit, but which is not res judicata as to absent members of the class. ${ }^{17}$ All three class actions should function to avoid the requirement of complete diversity in that it need only be satisfied by the class members who are original parties to the suit.18

It should be noted that although Moore states that the three categories of rule 23 are keyed to the binding effect of the judgment, it was the intent of the Advisory Committee that the rule be silent on the subject. Thus it is materially incomplete and stands only as an invitation to the courts to prescribe the substantive consequences. To this extent it is really no rule at all since it does not regulate the behavior of the courts. ${ }^{19}$ For example, there is nothing in the rule that would prevent a court from framing the judgment in a common question class suit to bind absentee members of the class, whether the judgment is favorable to their interests or not. Professor Moore was clearly troubled by the Committee's failure to key the classification to jurisdiction and res judicata as he had proposed; but "nowise discouraged at being thus locked out at the front door, Mr. Moore soon contrived to slip in by the back door. ... So great is the deserved respect for his treatise, that his scheme about binding outsiders has almost as much influence upon judges as if it had been embodied in Rule 23."'20

Kalven and Rosenfield were the first to take issue with the law as stated by Moore. ${ }^{21}$ They were concerned that there existed no practical means of redress for those who, like the individual investor in a reorgan-

15 Id. at 556. Moore \& Cohn, Federal Class Actions, 32 IL.. L. REv. 307,312 (1937).

16 Moore \& Cohn, Federal Class Actions-Jurisdiction and Effect of Judgment, 32 ILL. L. REv. 555, 559 (1938); Moore \&. Cohn, Federal Class Actions, 32 ILL. L. REv. 307, 317 (1937).

17 Moore \& Cohn, Federal Class Actions-Jurisdiction and Effect of Judgment, 32 ILL. L. REv. 555, 561 (1938); Moore \& Cohn, Federal Class Actions, 32 ILL. L. REv. 307, 320 (1937).

18 Moore \& Cohn, Federal Class Actions-Jurisdiction and Effect of Judgment, 32 ILL. L. REv. 555, 565 (1938).

19 Cf. Kalven \& Rosenfield, supra note 5 , at 705-07.

20 Chafee, Some Problems of Equity 251 (1950).

21 Kalven \&: Rosenfield, supra note 5. 
ization case, 22 find themselves "inadvertently holding a small stake in a large controversy ... [involving] immensely complex facts and intricate law, and redress for [which] is likely to involve expense totally disproportionate to any of the individual claims." 23 What was needed was to bring all the individual claims before the court for simultaneous adjudication. ${ }^{24}$ This could be best accomplished by a common question class suit, ${ }^{25}$ as provided in rule $23(a)(3) .{ }^{26}$ Although they assumed that class members who were not formal parties could not be bound by an adverse judgment, the action would be brought by a member of the class "on behalf of all, in the sense that if he is successful all may participate in the result." 27 To enable such participation the decree must be held open while the intervention of absent class members is solicited under judicial supervision. ${ }^{28}$ However, Moore's interpretation of the rule would not permit intervention after judgment, ${ }^{29}$ and thus the issue was joined.

As to Moore's description of the function of the "spurious" class suit Kalven and Rosenfield argued that the courts have already abandoned literal compliance with the diversity requirement in some large group cases $^{30}$ and that there is inadequate authority for the proposition that only the original plaintiffs need satisfy the jurisdictional amount. ${ }^{31}$ More

22 Other examples of such persons include "the employee who is entitled to time and a half for overtime, the stockholder who has been misled by a false statement in a prospectus, the ratepayer who has been charged an excessive rate, the depositor in a closed bank, the taxpayer who resists an illegal assessment, or the small businessman who has been the victim of a monopoly in restraint of trade . . . Id. at 684 .

23 Ibid.

24 Id. at 688.

25 The plaintiffs' committee, such as employed in corporate reorganizations, is rejected as a technique because (l) it requires extensive organization and aggressive solicitation to persuade enough plaintiffs to join the action, (2) such committees are generally distrusted on the basis of past performance, (3) the publicity necessarily incident to solicitation may adversely affect innocent defendants, (4) it is inadequate to overcome the apathy of the many injured parties, and (5) it offers too many opportunities for abuse of the powers of attorney by collusion. Id. at 688-91.

26 Since there are few circumstances in which joinder is compulsory, and bankruptcy and reorganization statutes regulate most of the situations in which property is before the court for distribution or management, the utility of $\S \S 23(\mathrm{a})(1)$ and (a)(2) is negligible. Id. at 703,705 .

27 Id. at 691 .

$28 I d$. at 688,695 .

292 Moore, Federal Practice II 23.04(3), 23.08 (1st ed. 1938).

30 Kalven \& Rosenfield, supra note 5, at 704 n.66.

31 Ibid. At present there is conflicting authority as to whether intervening class members need satisfy the jurisdictional amount, although the majority of cases agree with Professor Moore that the intervenors need not do so. Amen v. Black, 234 F.2d 12, 16 (10th Cir. 1956); Mutation Mink Breeders Ass'n v. Lou Nierenberg Corp., 23 F.R.D. 155, 162 (S.D.N.Y. 1959) (dictum); Local 900, Federated Independent Texas Unions v. Local 776, Int'l Ass'n of Machinists, 79 F. Supp. 554, 556 (N.D. Tex. 1948) 
importantly, most situations in which a "spurious" class action would be useful arise under federal laws. Thus in the federal courts the "spurious" suit performs no function not already performed by permissive joinder and intervention under rules 20 and $24 .{ }^{32}$ In addition to these criticisms Professor Chafee has observed another difficulty with Moore's general scheme. The cases do not lend themselves to the facile classification of rule 23, which leaves the non-litigating class members in doubt as to whether or not they will be bound by the result in the class action. The rule can become a trap if an absent class member relies on his being included in the judgment only to discover after the statute of limitations has run that the action was "spurious" and his motion to intervene untimely. ${ }^{33}$ Participation would avoid this unfortunate consequence.

Kalven and Rosenfield further argued that a consistent reading of rule 23 compels the conclusion that participation in the judgment by absent class members is permitted by the rule. In the first place to require all class members to become parties would render meaningless the notion expressed by the rule that the class is represented by the original parties to the suit. Moreover, the rule is only applicable "if persons constituting a class are so numerous as to make it impracticable to bring them all before the court." Hence, to require them to be made parties results in the absurdity of saying that even though it is impracticable to do so, they must be brought before the court anyway. The second line of argument was that subparagraph (c) is designed to protect absentee members of the class from unwarranted dismissal or compromise, but this can only have meaning if there are absentees to protect. Thirdly, since participation in judgment is characteristic of subsection (a)(1) and (a)(2), there is strong reason to believe that it is characteristic of (a)(3). ${ }^{34}$ Finally, since the rule says nothing about participation it is at least an open question.

(semble); Shipley v. Pittsburg \& L.E. R.R., 70 F. Supp. 870 (W.D. Pa. 1947); Hunter v. Southern Indem. Underwriters, 47 F. Supp. 242 (E.D. Ky. 1942). Contra, Steel v. Guaranty Trust Co., 164 F.2d 387 (2d Gir. 1947); Wagner v. Kemper, 13 F.R.D. 128 (W.D. Mo. 1952).

32 Kalven \& Rosenfield, supra note 5, at 704-05. In fairness it must be pointed out that some of the arguments employed by Kalven and Rosenfield are not without objection. There is little evidence to support the proposition that the courts are disregarding the diversity requirement. The avoidance of this requirement is clearly necessary if the federal courts are to try cases involving large groups which arise under state laws. Even this limited function gives some meaning to the concept of representation in that the original plaintiff is representative of the citizenship of the entire class. In spite of this weakness Kalven and Rosenfield appear to have the best of the argument. Rule 23(a)(3) as understood by Moore is so different from rules 23(a)(1) and (a)(2) that its inclusion in rule 23 instead of rule 20 results in much inconsistency and confusion in the meaning of the terms used.

33 ChafeE, op. cit. supra note 20, at 251-57. See York v. Guaranty Trust Co., 143 F.2d 503, 529 (2d Cir. 1944).

34 With respect to this third argument it should be noted that in "true" and 
Independent of its value as a plaintiffs' device, participation in judgment offers a means for reducing multiplicity of litigation and conserving the courts' time. Moreover, it reduces the number of potential situations in which different juries reach different conclusions as to the same issue of fact, thus preventing the kind of over-dramatization of a systemic malady which destroys confidence in the ability of the courts to administer justice. Consequently on numerous occasions courts have found themselves persuaded by the utility of the class action as described by Kalven and Rosenfield ${ }^{35}$ in spite of Professor Moore's protestations to the contrary. ${ }^{36}$ Assuming for the moment that these writers are correct in their belief that the absent class members could not be bound by an adverse judgment in a spurious class action, ${ }^{37}$ it is submitted that the Kalven and Rosenfield approach to the problem avoids the central issue, namely whether the doctrine of res judicata should be extended to permit participation in judgment.

Kalven and Rosenfield argued that whether participation will be permitted can be determined without reference to res judicata because no attempt is made to bind any party who has not had a full opportunity to litigate the issues upon which his liabilities or rights of recovery turn. They dismissed the notion that it is unfair to permit the absentees, who would not be bound by an adverse result, to make use of the favorable decree, observing that the defendant has had his day in court and to force the class to relitigate the issues is to treat litigation as a form of gambling in which to win one must bear the risk of losing. ${ }^{38}$

The courts, however, have long recognized a contrary doctrine. Under the label of mutuality of estoppel many cases hold that a prior judgment can be asserted as a bar to further litigation only by one who would have

"hybrid" class actions not only are the absent members allowed to participate in the judgment, they are bound by it.

35 Union Carbide \& Carbon Corp. v. Balsley, 300 F.2d 561 (10th Cir. 1961); York v. Guaranty Trust Co., 143 F.2d 503 (2d Cir. 1944) (dictum); State Wholesale Grocers, Inc. v. Great Atl. \& Pac. Tea Co., 24 F.R.D. 510 (N.D. Ill, 1959); Speed v. Transamerica Corp., 100 F. Supp. 461 (D. Del. 1951); Wilson v. City of Paducah, 100 F. Supp. 116 (W.D. Ky. 1951); Tolliver v. Cudahy, 39 F. Supp. 337 (E. D. Tenn. 1941); Alabama Independent Serv. Station Ass'n v. Shell Petroleum Corp., 28 F. Supp. 386 (N.D. Ala. 1939).

363 Moore, Fedfral Practice If 23.12 (2d ed. 1948) and cases cited therein; Bascom Launder Corp. v. Telecoin Corp., 204 F.2d 331 (2d Cir. 1953) (no participation where jury trial required); Kentucky Home Mut. Life Ins. Co. v. Duling, 190 F.2d 797 (6th Cir. 1951); Lockwood v. Hercules Powder Co., 7 F.R.D. 24 (W.D. Mo. 1947); Abran v. San Joaquin Cotton Oil Co., 46 F. Supp. 969 (S.D. Cal. 1942); Lofther v. First Nat'l Bank, 45 F. Supp. 986 (N.D. IIl. 1941).

37 See text accompanying notes 58-68 infra for a discussion of the developments which now make it possible to bind the absent class members.

38 Kalven \& Rosenfield, supra note 5, at 711-13. 
been bound by that prior judgment had it been adverse. ${ }^{39}$ Although the courts have been less than articulate in stating the rationale for mutuality and numerous commentators have attacked it in the interest of reducing the volume of litigation, ${ }^{40}$ the doctrine has shown remarkable durability ${ }^{41}$ and in most jurisdictions has given way only to recognized exceptions in which agency or suretyship doctrines compel a relaxation of mutuality to avoid inconsistent liabilities.42 The only further exception which has received any substantial degree of recognition is that suggested by Professor Currie in his analysis of Bernhard v. Bank of America Nat'l Sav. b Trust Ass'n.43 Under this proposal, one not bound by a prior judgment will be permitted to assert that judgment as a final adjudication of the issues previously litigated, but only if the party against whom it is asserted possessed the strategic advantages of initiative as plaintiff in the prior action. ${ }^{44}$ Kalven and Rosenfield on the other hand would have had the courts abandon mutuality altogether. In effect participation in judgment would permit persons not bound by a prior judgment to assert that judgment as a final adjudication of all issues which could have been litigated in the prior action, even though the one against whom it is asserted was the defendant in both actions. However, the apparent explanation for the continued vitality of mutuality is the concern on the part of the courts to avoid the unfairness which would result from the abandonment of the doctrine in this very situation.

Should mutuality be abandoned by permitting participation in judgment, an inequitable allocation of the risks of litigation between the class members and the defendant will inevitably result. The defendant will be forced to risk liability to the entire class while the establishing of his non-liability with respect to the actual litigants will be the most that he can gain. This would produce enormous pressures on the defendant

39 E.g., Lawler v. National Screen Serv. Corp., 349 U.S. 322, 329-30 (1955); Chase Nat'l Bank v. City of Norwalk, 291 U.S. 431, 438 (1934); Bigelow v. Old Dominion Copper Co., 225 U.S. 111, 127 (1912); Moore \& Currier, Mutuality and Conclusiveness of Judgments, 35 TuL. L. Rev. 301 (1961). The court in the Union Carbide case suggested that res judicata is inapplicable because no final judgment had been entered. 300 F.2d at 587. Though a technically sustainable position, this ignores the policies on which res judicata and mutuality are grounded.

40 E.g., Cox, Res Adjudicata: Who Entitled to Plead, 9 VA. L. REc. (n.s.) 241 (1923); Comment, 18 N.Y.U.L. REv. 565 (1941); Comment, 35 Yale L.J. 607 (1926); Note, 35 Texas L. Rev. 137 (1956); Note, I5 U. Cinc. L. Rev. 349 (1941); Note, 27 VA. L. Rev. 955 (1941).

41 Moore \& Currier, supra note 39 , at 301.

42 Id. at 311-26. E.g., a suit by a creditor against the principal debtor followed by a suit by the same creditor against the surety.

4319 Cal. 2d 807, 122 P.2d 892 (1942).

44 B. Currie, Mutuality of Collateral Estoppel: Limits of the Bernhard Doctrine, 9 STAN. L. REv. 281 (1957). 
to settle with any plaintiff class members whose claim is at all meritorious. The inequity would occur in its most egregious form should there be successive class actions by different members of the class. In each suit the defendant would be risking liability to all those not parties to previous litigation. Conceivably he could win a number of the suits and yet a single loss would bring massive liability. Should such a situation arise the courts ought to protect the defendant by refusing to permit more than one class action with respect to a single set of issues. Even this restriction does not prevent an absent class member from awaiting the outcome of the class action and either participating in a favorable judgment or bringing an action on his own should the result in the class action be adverse to the class. If different juries always reached the same result on an issue there would be no objection to allowing the subsequent actions and no utility in bringing them. The fact that judges and juries are often inconsistent and witnesses unpredictable demonstrates that there is a certain degree of chanciness to litigation and to require one party to assume significantly greater risks than his adversary is not only "contrary to better gambling etiquette," it is unfair. 45

Union Carbide of Carbon Corp. $v$. Balsley ${ }^{46}$ clearly reveals the circumstances in which this unfairness is most likely to occur and suggests some possibilities for its control. The thirty-six plaintiffs in this action recovered a multimillion dollar judgment for themselves, and the absent class members were permitted to come in and prove their own damages. It so happened that the class action had been instituted only a few months before the time for bringing the action expired, hence the absentees were barred from bringing new actions prior to the termination of the class action. ${ }^{47}$ Suppose, however, that prior to the expiration the thirty-six had failed in their attempt to recover. Unless they were precluded by stare decisis the absentees almost certainly would have brought individual suits, each for treble damages for hundreds of thousands of dollars.

Clearly this is not the situation Kalven and Rosenfield had in mind when they suggested that courts permit participation in judgment. They were concerned with protecting claimholders whose damages were too small to justify individual litigation. Such plaintiffs would not as a practical matter have multiple opportunities to establish the defendant's liability. The absent class members would also be prevented from bringing their own actions after the termination of the class action if the statute of limitations would bar the individual actions prior to the termination of the class action. This would occur when either the limitation on actions

45 See Louisell \& Hazard, Cases on Pleading and Procedure 718-23 (1962).

46300 F.2d 561, 587 (10th Cir. 1961).

47 Id. at $587-90$. 
is very brief, as in the case of the securities acts, 48 or the class action is brought close to the end of the period, as in the Union Carbide case. Perhaps, then, it would be possible to identify a sub-class which could be permitted to participate in the judgment because its members are unable to bring individual actions. Their recovery would be as effectively determined by the result in the class action as if they were legally bound by that result, and the defendant would not incur inequitable risks.

The problem with such a rule is to identify an appropriate sub-class. Where the statute of limitations is the effective bar to subsequent actions only those class members who have not filed suits before the statute runs constitute the sub-class. This prevents absent class members from filing individual suits and delaying to await the outcome of the class action. However, this delineation of the sub-class would restrict the operation of participation in judgment to those situations in which the statute has run before termination of the class action. So severe and arbitrary a restriction may require the conclusion that participation is not a broad enough remedy to justify the effort involved in its administration. Where the amount of the claim is the effective bar, the sub-class bound by the class action would consist of all those class members whose individual claims are for less than the amount necessary to justify undertaking the suit on one's own or, resorting to a more mechanical form, all those with claims less than $\$ 5,000$. The objection to the former delineation of the sub-class is that it is too uncertain and too difficult of accurate determination, while the latter ignores the great variance in costs and fees depending upon the complexity of the litigation. More important, a group of claimants unable to maintain individual actions can always join together in a single suit and share the costs. Thus the absent class members would be able to bring subsequent actions against the defendant, resulting in the very unfairness which is sought to be avoided.

Not only does participation in judgment lend itself to abuses difficult to control, but it would appear that in many circumstances the device will not be as effective in aiding the small claimholders to maintain the class action as its proponents have supposed. The chief barrier to the effectiveness of participation is the lack of funds at the plaintiff's disposal with which to prosecute the litigation. Kalven and Rosenfield suggested providing for attorneys' fees and expenses out of the fund recovered on a quantum meruit basis.9 ${ }^{49}$ However, as Professor Chafee has cautioned,

48 Securities Act of 1933, 48 Stat. 84 (1933), as amended, 15 U.S.C. $\$ 77 \mathrm{~m}$ (1958); Securities Exchange Act of 1934, 48 Stat. 898 (1934), as amended, 15 U.S.C. $\S 78 \mathrm{r}(\mathrm{c})$ (1958). Both acts limit the bringing of actions to one year from the time the misrepresentation was or should have been discovered, but in no event longer than three years from the time the cause of action accrued.

49 Kalven \& Rosenfield, The Contemporary Function of the Class Suit, 8 U. CHI. L. REv. 684, 691, 714-21 (1941). 
"class suits are sometimes lost." 50 In such a case who will provide the expenses of litigation? The partial solution suggested by Chafee is utilization of the contingent fee. ${ }^{51}$ However, a contingent fee requires a contract between attorney and client, and the attorney cannot possibly contract with the absent class members, whose recovered damages are the only adequate source of fees. Hence this device is unavailable, and attorneys will probably be willing to undertake the litigation only if they expect the quantum meruit fee to be large enough to justify the risk of receiving no fee at all.

As an alternative to participation in judgment it has been suggested that rule 23(a)(3) be regarded as a special instance of permissive joinder which may be supplemented by direct solicitation of the absent class members at the outset of the litigation..$^{52}$ Only those who join and share the expenses would be allowed to benefit from a favorable judgment; thus the absent class members would have no unfair advantages over the defendant, and the attorney could secure a contingent or non-contingent fee contract from the litigating class members. Since the solicitation would be under the court's supervision it could be made clear at the outset that no implication of judicial approval of the plaintiff's claims is intended and the absent class could be protected from misleading propaganda. The names of those to be solicited would usually be available from the defendant's records on discovery.

However, solicitation has its own species of abuse. Even a carefully worded notice will produce publicity unfavorable to the defendant, who is quite possibly innocent, and if the publicity is directed specifically toward persons upon whose goodwill the defendant is dependent he may be eager to settle to escape the notoriety. If, for instance, the action is against a corporation for misstatement in a prospectus, notice to its stockholders might bring about widespread selling of the corporation's stock with consequent ill effects on its financial position. In most other situations the effect of bad publicity probably would be no more severe than is the case in any litigation.

Solicitation, like participation in judgment, could be a powerful weapon in the hands of the strike-suiter, who brings lawsuits solely for the purpose of coercing from the defendant a secret settlement. Either procedure can result in a large judgment and by compromising a claim infinitesimal in comparison the defendant can remove this risk of massive liability. Although it is true that the court may be able to prevent compromise or abandonment of a class action and thus defeat the strike-

50 ChAFEe, op. cit. supra note 20, at 278 .

51 Id. at 279.

ש2 Cherner v. Transitron Electronic Corp., 201 F. Supp. 934 (D. Mass. 1962); Hormel v. United States, 17 F.R.D. 303 (S.D.N.Y. 1955). 
suiter, ${ }^{53}$ the alert practitioner will not at first bring the suit as a class action. Instead he will count on the defendant to realize that the situation is so adapted to such procedure that he will wish to settle the claim as quickly as possible to avoid its becoming a class action at a later stage of the litigation. To maximize his bargaining power the strike-suiter will arrange for the settlement to be carried out immediately prior to the time the statute of limitations will foreclose the bringing of further suits by the class. Thus by settling this one action the defendant buys total immunity.

It is important to note, however, that the strike-suiter whose activity is of special concern is not one whose bargaining power rests solely on the nuisance value of the suit (i.e., the high cost of litigation to the defendant) but rather one whose action has some chance of succeeding. The latter performs a valuable policing service since the threat of a strikesuit may deter unlawful behavior. The objection to his activity is that the recovery belongs not to him but to the whole class, although he is the only one who benefits. Moreover, the threat of solicitation so increases the bargaining power of such a strike-suiter that the defendant is forced to make large settlements for doubtful claims. Even if his chance of success is one-in-ten, when the potential liability to the class is large it may be worthwhile for the defendant to settle for an amount much in excess of any possible claim the strike-suiter may have individually. One important qualification to this discussion arises from the uncertainty as to whether such strike-suiters do in fact exist or whether they are figments of the sensitive imaginations of corporate defendants. ${ }^{54}$ To the extent that the latter is the case this objection to solicitation loses its force.

Solicitation has proven to be unacceptable to the courts for another reason: judges suspect that they are being used by lawyers as vehicles for client solicitation. ${ }^{55}$ Indeed the champertous lawyer would be heartened by the court's adopting this device. He could seek out an initial plaintiff, solicit the class members for contributions which would cover his immediate needs and face the happy prospect of several hundred thousand dollars in contingent fees should the action succeed or result in a settlement. However, to some extent the courts' concern is misplaced. If the initial claim had not been brought into court through champertous activity, the solicitation would not be tainted as such. Had the client on his own initiative undertaken to bring together some members of the class through private

53 FED. R. Civ. P. 23(c) (retained in the proposed amendment as subdivision (e)).

54 See generally 2 Hornstein, Corporation Law and Practice §§ 722, 734 (1959); Hornstein, New Aspects of Stockholders' Derivative Suits, 47 Colum. L. REv. 1 (1947). 55 Cases cited note 52 supra. 
solicitation and had this group hired an attorney to bring the action, it would be difficult to find fault with the behavior of any of the parties. The step which the court is reluctant to take is the granting of a motion for discovery which would permit the plaintiff to obtain the information necessary for effective solicitation, ${ }^{56}$ for although the combination of discovery and solicitation is not champertous in itself, the availability of such procedure is an incentive to champerty. It would seem that any violations of the Canons of Professional Ethics ${ }^{57}$ which the adoption of this procedure might bring should be dealt with by more vigorous policing of the bar rather than by the elimination of all means of recovery which, due to their effectiveness, are necessarily incentives to champerty.

The alternative to all of the above proposals is to permit the absent class members to be bound by the judgment in the class action, whether it is favorable or unfavorable to their interests.58 Indeed this was the approach taken by the Advisory Committee on Civil Rules when it recently undertook the task of revising rule 23 . Subsection (c)(2) of the proposed rule provides:

The judgment in an action maintained as a class action shall extend by its terms to the members of the class, as defined, whether or not the judgment is favorable to them.... To afford members of the class an opportunity to request exclusion, the court shall direct that reasonable notice be given to the class ....59

Subsection (d)(2) would authorize the court to make orders

requiring, for the protection of the members of the class or otherwise for the fair conduct of the action, that notice be given in such manner as the court may direct to some or all of the members of ... the proposed extent of the judgment ..... ${ }^{60}$

56 Ibid.

57 American Bar Association, Canons of Professional Ethics §§ 27, 28 (1963).

68 This approach was first suggested in Keefe, Levy \& Donovan, Lee Defeats Ben Hur, 33 CORNELL L.Q. 327 (1948), which foresaw the development of notice as a standard of due process in the substituted service of process permitted by the non-resident motorist statutes. In only a few cases have the absent class members protested when courts have extended an adverse judgment in a class action to include them. Hansberry. v. Lee, 311 U.S. 32 (1940); Supreme Tribe of Ben-Hur v. Cauble, 255 U.S. 356 (1921). Presumably they are discouraged from bringing subsequent actions by the effects of stare decisis and the previous failure of the class to recover a favorable judgment.

59 Committee on Rules of Practice and Procedure of the Judicial Conference of the United States, Preliminary Draft of Proposed Amendments to Rules of Civil Procedure for the United States District Courts 97 (1964).

60 Id. at 98 . 
The Committee scrapped Moore's categories as unworkable and rejected participation in judgment and solicitation for reasons not entirely clear from the Committee's notes. ${ }^{61}$

In order to bind the absent class members it is necessary to satisfy the requirements of due process. ${ }^{62}$ This is the purpose of giving notice to the class. ${ }^{63}$ In a dictum in Hansberry $v . L^{2} e^{64}$ the Supreme Court suggested that there would be no constitutional barrier to "a procedure whereby some of the members of the class could stand in judgment for all, provided that the procedure were so devised and applied as to insure that those present are of the same class as those absent and that the litigation is so conducted as to insure full and fair consideration of the common issue."65 A few years later, in Mullane v. Central Hanover Bank \& Trust Co., ${ }^{60}$ the Court held that notice was sufficient to satisfy due process providing it was reasonably calculated to reach those sought to be bound by the judgment. ${ }^{67}$ Since this development of notice as a standard for measuring due process was not complete until 1950, it was unavailable to both Moore and Kalven, and almost all courts have refused to frame the judgment in "spurious" class actions in terms which would purport to bind the absent class members. ${ }^{68}$

Extending the judgment to the entire class would provide the small claimholders with an effective means of group redress. The prospect of a large judgment would be incentive for the plaintiff and his lawyer to prosecute the action with diligence. Normally the lawyer could expect at least reasonable fees on a quantum meruit basis, and perhaps the court would allow him to negotiate with the representatives of the class for a contingent fee contract which would be binding on the entire class. In addition, the device permits the courts to clean up a litigious situation without the inequitable allocation of risks inherent in participation in judgment.

Unfortunately notification is subject to many of the same objections as

61 Id. at $98-115$.

62 Pennoyer v. Neff, 95 U.S. 714 (1878).

63 Commrttee on Rules of Practice and Procedure, op. cit. supra note 59, at 119-14. 64311 U.S. 32 (1940).

65 Id. at 43 .

: 66339 U.S. 306 (1950).

67 Id. at 314; see Louisell \& HAZARD, op. cit. supra note 45, at 718-23.

68 E.g., Union Carbide \& Carbon Corp. v. Balsley, 300 F.2d 561, 589 (10th Cir. 1961); Kainz v. Anheuser-Busch, Inc., 194 F.2d 737 (7th Cir. 1952); Oppenheimer v. F.J. Young \& Co., 144 F.2d 387 (2d Cir. 1944); York v. Guaranty Trust Co., 143 F.2d 503 (2d Cir. 1944), rev'd on other grounds, 326 U.S. 99 (1945); Cutler v. American Fed'n of Musicians, 211 F. Supp. 433 (S.D.N.Y. 1962), aff'd, 316 F.2d 546 (2d Cir.), cert. denied, 375 U.S. 941 (1963); Mutation Mink Breeders Ass'n v. Lou Nierenberg Corp., 23 F.R.D. 155 (S.D.N.Y. 1959). But cf. Weeks v. Bareco Oil Co., 125 F.2d 84 (7th Cir. 1941). 
is solicitation. Like solicitation it can be a vehicle for unfavorable publicity and a powerful weapon in the hands of a strike-suiter ${ }^{69}$ It may also be a boon to the champertous lawyer; in fact the Advisory Committee has cautioned: "Notice is available fundamentally 'for the protection of the members of the class or otherwise for the fair conduct of the action' and should not be used merely as a device for the undesirable solicitation of claims." 70 But how is a court to determine whether a class action is brought for champertous purposes if the plaintiff otherwise satisfies the prerequisites for maintaining a class action? The attorney need not bring his motives into question by requesting that the class be solicited, as was the case in Cherner v. Transitron Electronic Corp., ${ }^{71}$ for the court must see to it that the class knows of the litigation. This in itself may be enough to elicit voluntary financial aid from some of the class members who are especially concerned with the outcome due to the size of their claims. If such aid is insufficient the plaintiff may indicate to the court that he is not able to continue the class action due to lack of funds. In such circumstances the court will often have no alternative other than to allow solicitation of the class, because a dismissal without prejudice will often be impossible since the statute of limitations may have run on many of those relying upon the action. Thus the champertous attorney is at a great advantage. He can seek out an initial plaintiff and face the happy prospect of substantial fees in the event the class recovers damages with little chance of being entirely unpaid if the action fails.

That there is a policy against champertous conduct by attorneys is certain. Whether it is well founded is another matter. The case against champerty rests on the reluctance to permit lawyers to profit by stirring up conflict. However, in the complexity of modern society it is often very difficult for the small claimholder to become aware that his rights have been infringed unless someone with knowledge of the relevant facts and law alerts him. A stockholder, for instance, can hardly be expected to comprehend the intricacies of the case law and regulations under the securities acts as to what constitutes a misstatement in a prospectus even in the rare case where he is in possession of all the facts. It would appear then that because of the prohibition against champerty some undetermined number of meritorious claims go unredressed through no fault of

69 See text accompanying note 53 supra. It is not at all clear who will bear the cost of notice, which will be substantial when the class is numbered in the thousands. The plaintiff can be said to have volunteered to bear the cost by bringing the action as a class action. Should the class recover a judgment he could seek reimbursement out of those funds. However, the immediate expense may be too much for the plaintiff to bear, in which case the court would have to bear the cost if the action is to continue. When the court initiates the class action presumably it must provide for the notice.

70 Commttiee on Rules of Practice and Procedure, op. cit. supra note 59, at 114.

71201 F. Supp. 934 (D. Mass. 1962). 
the injured party. Moreover, where a class action is involved, concern with the attorney's profiting excessively is somewhat misplaced since his fees will be awarded by the court on a quantum meruit basis. However, insofar as the policy against champerty still has force it stands as an objection to the adoption of solicitation and notification.

It would appear that each of the general procedures which have been devised to enable the small claimholder to recover is subject to uncontrollable abuses, and the more effective a procedure is in facilitating recovery, the more profitably it can be employed by the strike-suiter and the champertous lawyer. Hence the adoption of any of them would be unjustified if more selective and less abusive means of group redress are available. Kalven and Rosenfield have suggested a number of recurrent situations in which special means of redress for the small claimholder may be necessary..$^{72}$ An analysis of these and other situations suggests that in most of them adequate means exist to enable small claimholders to recover, and where such means are lacking changes in the substantive law could correct the deficiency.

For employees suing to recover overtime pay or minimum wages Congress has already provided a class action in which recovery is limited to those class members who designate the party plaintiffs as their agents. ${ }^{73}$ Even in absence of this provision no class action is needed because rule 20 permits persons whose recovery depends upon a common question of law or fact to join their claims in a single action. ${ }^{74}$ Since the injured employees are usually concentrated in a relatively small area, there would be little problem in joining enough claims to make the action financially feasible. Additional relief is available through the Wages and Hours Division of the Department of Labor which has the power through the Secretary of Labor to sue on behalf of employees. ${ }^{75}$

Beneficiaries of a common trust fund can be protected by the courts of equity. Professor Scott notes "there is . . . a modern tendency in the United States for a court which has supervision over the administration of trust estates to enforce the duties of trustees even though not called upon by the beneficiaries to do so." 76 Should one beneficiary sue to surcharge the trustees the court could extend relief to the beneficiaries as a class on its own initiative, and the beneficiary suing could be reimbursed for his costs from the trust fund since his efforts benefited all. ${ }^{77}$ These powers of

72 Kalven \& Rosenfield, supra note 49 , at 684.

73 Fair Labor Standards Act of 1938 § 16(b), 52 Stat. 1069, as amended, 75 Stat. 74 (1961), as amended, 27 U.S.C. $\$ 216$ (b) (Supp. V, 1964).

74 FED. R. Civ. P. 20.

7575 Stat. 74 (1961), 29 U.S.C. \$§ 216-17 (Supp. V, 1964).

76 3 SCotT, TRusts 1506 (2d ed. 1956).

7̇7 See Sprague v. Ticonic Nat'l Bank, 307 U.S. 161 (1939). 
the courts are supplemented in almost every jurisdiction by statutes regulating common trust funds. ${ }^{78}$ Some jurisdictions, such as New York, even provide for the appointment of a guardian to represent the absent beneficiaries in any accounting..$^{79}$ Moreover, Mullane v. Central Hanover Bank \& Trust Co. ${ }^{80}$ has established a high standard of notice to the beneficiaries, which must be complied with before an accounting can be res judicata as to their interests. ${ }^{81}$

Taxpayers resisting a special assessment for a sewer line or other improvement are of necessity grouped in a relatively small, well-defined locality. Thus the identity of the class can be easily ascertained, and a taxpayer can contact his fellow class members with little difficulty. If the class is sufficiently interested in resisting the assessment they can hire a lawyer and join in a single action under rule 20.82

Investors involved in corporate reorganizations are amply protected by a variety of devices. The protective committee is a well developed institution in this field which has been successful in mobilizing a class of investors and participating in the litigation on their behalf. Kalven and Rosenfield distrusted the reorganization committee due to the potential for collusive activity between the committee and the reorganization managers, the bankers and corporate officers. ${ }^{83}$ However, this possibility of collusion has been largely obviated by powers given to the court to disregard the delegation of authority by investors to the committee where it appears that the latter is exercising its power unfairly. ${ }^{84}$ Moreover, the committee is required to disclose the circumstances which led to its organization and the financial stake of its members in the reorganization. ${ }^{85}$ In addition the SEC has the authority to intervene to attack the reorganization plan if it is unfair to investors or others. ${ }^{86}$ The class suit would be an unnecessary appendage to these already complex proceedings.

The rates charged by public utilities are almost universally regulated by state and federal utilities commissions. ${ }^{87}$ The constant policing of

782 Scott, TRUSTs 1685 n.26 (2d ed. 1956).

70 N.Y. Banking Law \& 100-c(12); see also Mullane v. Central Hanover Bank \& Trust Co., 339 U.S. 306 (1950).

80339 U.S. 306 (1950).

81 Ibid.

82 The same factors would be operative in any case where landowners' property has been injured due to the activity of another party (e.g., riparian owners suing for diversion of water).

83 Kalven \& Rosenfield, note 49, at 684, 688-91 (1941); see note 25 supra.

84 Bankruptcy Act, 52 Stat. 895 (1938), 11 U.S.C. § 612 (1958).

85 Bankruptcy Act, 52 Stat. 895 (1938), I1 U.S.C. $\$ 611$ (1958).

86 Bankruptcy Act, 52 Stat. 894 (1938), 11 U.S.C. $\$ 608$ (1958).

87 E.g., IxL. Rev. Stat, ch. 111 2/3 (1963). 
fixed rates in itself reduces the chance of overcharges. However, obtaining an injunction against overcharges is often a lengthy business even for a commission, and in the meantime the ratepayers will have been paying the excessive rate. To remedy this the regulatory law could be amended to require the utility company to place the alleged excess in a fund during the pendency of the injunctive action. Should the injunction be granted the fund would be redistributed among the ratepayers. A similar procedure is now available to the FPC under the Natural Gas Act. ${ }^{88}$ If it is felt that an easily utilized civil action by ratepayers is essential to the enforcement of regulation, the act could provide for a class action permitting participation in judgment, since the individual claims will almost always be too small to justify subsequent actions. Notification or solicitation would be too expensive due to the large size of the class.

Stockholders suing a corporation for misrepresentation in a prospectus or suing the directors for mismanagement have often attempted to utilize the class action. Yet it is this situation which most easily lends itself to the abuses inherent in notification, solicitation, or participation. Absent these devices the small claimholder will sometimes be able to join with a plaintiff whose claim is large enough to warrant an individual suit, ${ }^{89}$ but this is often not possible due to the dispersion and anonymity of stockholders. To facilitate such joinder the SEC could be given authority to act as a clearing house for information concerning pending suits by stockholders anywhere in the United States. The necessary information could be given to any stockholder upon his request; in addition the Commission could bring together those stockholders who have requested such information but who have not yet filed suit. If this were felt to be inadequate to protect the class and to deter misrepresentations Congress could authorize the SEC to sue on behalf of the stockholders or to give them notice of the alleged misrepresentations.

In the vast majority of cases depositors in a bank which has failed will not need a class action. Federal deposit insurance, which covers all but a small percentage of bank deposits, ${ }^{90}$ will prevent injury to those depositors with $\$ 10,000$ or less in their accounts. Those with claims for greater amounts usually will have a large enough stake in the outcome to warrant bringing their own actions. In addition depositors ordinarily reside in the locality of the bank, making joinder feasible.

8852 Stat. 822 (1938), as amended, 15 U.S.C. § 717c (1958); see Atlantic Ref. Co. v. Public Serv. Comm'n, 360 U.S. 378 (1958).

89 See, e.g., Cherner v. Transitron Electronic Corp., 221 F. Supp. 48 (D. Mass. 1963).

90 Of the $\$ 365,262$ millions on deposit in banks, $\$ 313,304$ millions were insured by the Federal Deposit Insurance Corporation, leaving only $14.2 \%$ of all deposits uninsured. Moreover, only about $3 \%$ of all banking institutions are uninsured. BurEAu OF THE Census, Statistical Abstract of the United States 457 (1964). 
Insofar as reliance upon an administrative agency is the alternative to some form of class action it must be recognized that proceedings before these agencies may lend themselves to abuses similar to those inherent in class actions. Where the agency proceedings are judicial in form the attraction of even quantum meruit fees may incite the champertous attorney. Where the agency conducts its own investigation independent of the parties the threat of involvement with the agency may provide leverage for extortion similar to that practiced by the strike-suiter. However, this would be a much less effective technique than that of the strike-suiter for there is no effective way to prevent either the person threatening to alert the agency or other members of the class from subsequently involving the agency. At present there is no indication that unscrupulous attorneys have made such use of agency proceedings.

It would appear that in the circumstances in which some form of class action could usefully be employed, there are or could be made available other more selective procedural remedies which for the most part avoid the abuses of the class action and yet facilitate recovery by the small claimholder. Subsection (b)(3) of the proposed revision of rule 23 provides that a class action which is based only on the existence of a "common question" shall be permitted only if it "is superior to other available methods for the fair and efficient adjudication of the controversy." 91 Where a class action is brought to recover damages this provision, if adopted, should be strictly construed to limit the use of the class action to those situations in which other methods of redress are unavailable, that is, where the class is dispersed and the claims small, and no aid from an administrative agency is available. The rule, so construed, is clearly superior to existing rule 23 which has been clouded by interpretations that render it confusing and self-contradictory. ${ }^{92}$ Should the proposed rule not be adopted all of the problems of notification, solicitation, and participation in judgment will still exist because rule 23 as it now stands does not forbid the use of any of these procedures. Hence the Supreme Court may be called upon to decide which ones are appropriate. An ideal solution will be impossible, because any procedure that makes it easy for a class to recover damages necessarily creates a potential for abuse.

91 Committee on Rules of Practice and Procedure, op. cit. supra note 59, at 96.

92 Chafee, Some Problems in Equity 244-61 (1950); Commrttee on Rules of Practice and Procedure, op. cit. supra note 59, at 98-101; Kalven \& Rosenfield, supra note 49 , at $695-710$. 